\title{
PENGEMBANGAN POTENSI PEMUDA - PEMUDI BANDUNG MELALUI GERAKAN KEWIRAUSAHAAN SOSIAL
}

\author{
OLEH : \\ SALSABILA WAHYU HADIANTI ${ }^{1}$, YANA SAFITRI ${ }^{2}$ \\ ${ }^{1}$ Mahasiswa S1 Program Studi Kesejahteraan Sosial, Fakultas Ilmu Sosial Dan Ilmu Politik, \\ Universitas Padjadjaran, Jl. Raya Bandung - Sumedang Km. 21 Jatinangor 45363. \\ ${ }^{2}$ Mahasiswa S1 Program Studi Kesejahteraan Sosial, Fakultas Ilmu Sosial Dan Ilmu Politik, \\ Universitas Padjadjaran, Jl. Raya Bandung - Sumedang Km. 21 Jatinangor 45363.
}

(Penulis)

\begin{abstract}
Abstrak
Permasalahan pada kota - kota besar di Indonesia tentunya semakin hari semakin kompleks, hal ini jugalah yang sama dialami oleh Kota Bandung. Walaupun Kota Bandung saat ini telah melakukan banyak inovasi dan pengembangan, namun sayangnya Kota Bandung sendiri tidak dapat menghindari beragam permasalahan sosial yang ada. Salah satu upaya dalam mengatasi persoalan di Kota Bandung sendiri salah satunya yakni melalui gerakan kewirausahaan sosial dengan melibatkan generasi muda (pemuda - pemudi) Kota Bandung yang terkenal kreatif sebagai potensi bagi Kota Bandung sendiri. Praktik kewirausahaan sosial ini merupakan sebuah alternatif berbasis masyarakat yang berpotensi menyempurnakan proses pembangunan, dimana masyarakat dijadikan partner dalam proses pembangunan. Dengan adanya gerakan kewirausahaan sosial, hal ini tentunya mendorong kita untuk dapat memecahkan permasalahan sosial bukan didasarkan kepada hal - hal yang bersifat patologis semata, melainkan melalui pengembangan potensi melalui kegiatan - kegiatan yang menyenangkan.
\end{abstract}

Keywoard: Kota Bandung, Pemuda - Pemudi, Kewirausahaan Sosial.

\section{A. PENDAhuluan}

Sebagaimana yang dikemukakan oleh Lughod (1991) bahwa perkotaan merupakan wilayah yang identik dengan beragam permasalahan yang menimpa warga masyarakatnya. Pernyataan ini semakin 
diperkuat dengan adanya pendapat Klenewsky (1997:3) yang menyatakan bahwa hal ini terjadi karena perkotaan merupakan tempat bertemunya ketidakseimbangan antara kesejahteraan dan kemiskinan, kontradiksi antara pertumbuhan dan kemunduran, dan kontras antara kerja sama sosial dan persaingan.

Permasalahan pada kota - kota besar di Indonesia tentunya semakin hari semakin kompleks. Sebagaimana yang dikemukakan oleh Budiharjo terkait beragam permasalahan sosial yang muncul di kota - kota besar :

"Kota - kota besar di berbagai penjuru tanah air mengalami krisis yang belum pernah diderita sebelumnya. Sumpek macet, banjir, tercemar (baik secara fisik maupun budaya), menimbulkan degradasi lingkungan dan dehumanisasi. Angka kriminalitaspun meningkat, kenakalan anak - anak merebak, tawuran pelajar serta narkotika dan obat - obatan berbahaya (narkoba) merajalela" (Budiharjo, 2014:43)

Walaupun saat ini Kota Bandung telah melakukan inovasi dan pengembangan, namun sayangnya Kota Bandung sendiri tidak dapat menghindari beragam permasalahan sosial sebagaimana yang dikemukakan diatas.

Salah satu upaya yang dapat dilakukan dalam mengatasi permasalahan sosial yang ada di Bandung yakni melalui gerakan kewirausahaan sosial. Hal ini didasari dengan meninjau klasifikasi penduduk Kota Bandung sendiri dilihat dari kelompok umur (usia produktif) yang menunjukan presentase yang cukup besar. Hal inilah tentunya dapat menjadi potensi bagi Kota Bandung sendiri, terlebih generasi muda Kota Bandung terkenal kreatif dan sudah tidak diragukan lagi bahwa mereka pun sering memunculkan berbagai ide-ide kreatif.

Tabel 1. Penduduk Kota Bandung Menurut Kelompok Umur

\begin{tabular}{|c|c|c|c|c|c|}
\hline \multirow{2}{*}{ No. } & \multirow{2}{*}{ KELOMPOK UMUR } & \multicolumn{3}{|c|}{ Jumlah Penduduk } & \multirow{2}{*}{ Persentase } \\
\hline & & $\mathrm{L}$ & & Jumlah & \\
\hline 1 & 0.4 & 72.074 & 67.439 & 139.513 & $5 \%$ \\
\hline 2 & 5.8 & 84.462 & 79.394 & 163.856 & $6 \%$ \\
\hline 3 & $9-12$ & 92.703 & 87.323 & 180.026 & $7 \%$ \\
\hline 4 & $13-16$ & 87.325 & 82.959 & 170.284 & $6 \%$ \\
\hline 5 & $17 \cdot 20$ & 87.342 & 83.620 & 170.962 & $6 \%$ \\
\hline 6 & $21 \cdot 24$ & 84.435 & 81.226 & 165.661 & $6 \%$ \\
\hline 7 & $25-28$ & 96.025 & 93.261 & 189.286 & $7 \%$ \\
\hline 8 & $29-32$ & 118.533 & 112.333 & 230.866 & $9 \%$ \\
\hline 9 & $33-36$ & 110.558 & 105.297 & 215.855 & $8 \%$ \\
\hline 10 & $37-40$ & 102.734 & 96.178 & 198.912 & $7 \%$ \\
\hline 11 & 41.44 & 94.207 & 87.432 & 181.639 & $7 \%$ \\
\hline 12 & $45-48$ & 77.911 & 74.039 & 151.950 & $6 \%$ \\
\hline 13 & 49.52 & 64.828 & 62.835 & 127.663 & $5 \%$ \\
\hline 14 & 53.56 & 55.271 & 52.154 & 107.425 & $4 \%$ \\
\hline 15 & $57-60$ & 45.609 & 41.463 & 87.072 & $3 \%$ \\
\hline 16 & 61.64 & 30.501 & 29.008 & 59.509 & $2 \%$ \\
\hline 17 & $>65$ & 72.197 & 80.824 & 153.021 & $6 \%$ \\
\hline & Jumlah & 1.376 .715 & 1.316 .785 & 2.693 .500 & $100 \%$ \\
\hline
\end{tabular}

(Sumber: Database SIAK Tahun 2013)

\section{B. ISI}

Sebagaimana yang dikemukakan sebelumnya, salah satu bentuk praktik yang saat ini semakin tumbuh populer dan terasa manfaatnya sebagai partner pembangunan yakni gerakan kewirausahaan sosial. Hal ini dikarenakan melalui gerakan kewirausahaan sosial setiap elemen masyarakat dijadikan partner dalam aktivitas pembangunan, artinya sistem yang digunakan bukan lagi berbasis top down dimana pemerintah memegang kendali atas proses pembangunan melainkan melalui 
kewirausahaan sosial proses pembangunan dilaksanakan secara bottom - up yakni proses pembangunan justru berasal dari masyarakat yang dapat menunjang aktifitas pembangunan atau kebijakan pemerintah itu sendiri.

Pendapat ini semakin diperkuat melalui pendapat Skoll yang dikutip dalam buku yang ditulis oleh Herry Wibowo dan Sonny A. Nulhaqim, yang menjelaskan bahwa kewirausahaan sosial merupakan sebuah antitesis dari program pembangunan berbasis sosial politik yang cenderung memaksakan model top down kepada masyarakat (Skoll dalam Herry\&Soni, 2015:109)

Kewirausahaan sosial dalam hal ini adalah sebuah gerakan yang didalamnya terdapat nilai pemberdayaan, membangun masyarakat, mentransformasikan insitusi dan juga meningkatkan solusi dan membawa dampak positif bagi masyarakat luas dalam pemecahan masalah sosial. Hal ini menunjukan bahwa gerakan kewirausahaan sosial merupakan kegiatan yang ceria, menyenangkan, kreatif, dan dapat dijadikan sebagai wadah penyaluran minat dan bakat yang dimiliki masyarakat. Dengan begitu, proses gerakan kewirausahaan sosial justru tidak berwujud sebagai bentuk "sumbangan" yang tentunya dapat membuat masyarakat penerima bantuan mejadi pasif.

Dalam pelaksanaan praktiknya, tentunya terdapat perbedaan mendasar antara praktik kewirausahaan sosial dan kewirausahaan biasa (bisnis) sebagaimana yang dikemukakan oleh Prof. Dr. H. Muhammad Djakfar, S.H., M.Ag :

"Dalam kaitan ini nampaknya dibedakan antara kewirausahaan sosial dengan kewirausahaan bisnis dalam banyak hal. Antara lain, kewirausahaan sosial berjalan dengan sebuah misi sosial yang jelas (eksplisit). Tujuan mereka adalah menjadikan dunia yang lebih baik. Hal ini mempengaruhi bagaimana mereka mengukur kesuksesan mereka dan mestruktur pengelolaannya. Menurut Dees cara terbaik mengukur kesuksesan kewirausahaan sosial bukan dengan menghitung jumlah profit yang dihasilkan, melainkan pada tingkat mana mereka telah menghasilkan nilai - nilai sosial (social value)" (Djakfar, 2012:22)

Ketika kewirausahaan biasa (bisnis) bertujuan untuk menggali keuntungan sebanyak - banyaknya dan meminimalkan pengeluaran sebagai biaya produksi, kewirausahaan sosial justru bergerak sebagai pelopor yang membawa misi sosial dan semangat untuk pemberian manfaat yang sebesar - besarnya.

Salah satu contoh konkret gerakan kewirausahaan sosial yang sudah dilaksanakan di Bandung diantaranya yakni Sanggar Waringin. Sanggar Waringin yakni sebuah praktik kewirausahaan sosial yang aktivitasnya dibangun di tengah Terminal Angkutan Kota Stasiun Hall Bandung. Inti dari aktivitas praktik kewirausahaan sosial yang berada di St- Hall Bandung ini adalah upaya menunjang program pemerintah dalam bidang pendidikan.

Selain Sanggar Waringin juga terdapat gerakan kewirausahaan sosial lainnya yakni 
Kumble Store yakni sebuah gerakan kewirausahaan sosial yang dilatarbelakangi oleh misi meminimalisir jeans yang sudah tidak terpakai menjadi barang yang layak pakai. Gerakan kewirausahaan sosial ini dipelopori oleh 6 mahasiswa aktif mahasiswa jurusan Kesejahteraan Sosial FISIP UNPAD.

Walaupun banyak yang menganggap bahwa aktifitas kewirausahaan sosial bukan sebuah aktivitas yang mudah dikelani dan diterjuni namun bukan tidak mungkin untuk mencoba gerakan ini yakni salah satunya melalui pemberian pendidikan terkait kewirausahaan sosial yang tentunya diberikan secara konsisten.

"Pola pendidikan kewirausahaan yang dianjurkan adalah yang mendorong siswa tidak sekedar mengenal (to know) atau mempelajari konsep konsep (to learn) tentang kewirausahaan, namun yang mendorong mereka untuk menjadi wirausaha (to be entrepreneur). Artinya, titik tekan kurikulum didorong untuk lebih berat kepada praktik (practices) daripada sekedar berkutat diranah kognitif." (Wibowo \& Nulhaqim, 2015:88)

Manfaat dari mempelajari kewirausahaan sosial tentunya tidak hanya ditunjukan bagi pemecahan masalah sosial melainkan juga sebagai bentuk pengembangan potensi individu. Sebagaimana yang dikemukakan oleh Herry Wibowo dan Soni A. Nulhaqim:

"Satu hal bawa, yang mereka lakukan di jenjang pendidikan, juga akan menambah emploibilitas mereka.
Jikapun mereka menjadi pegawai, semangat kerja mereka akan diliputi rasa inovatif, inisatif, dan keberanian untuk menjelajah keranah kebaruan (out of the box), sehingga berpotensi menghasilkan produktifitas yang optimal" (Wibowo \& Nulhaqim, 2015:89)

Berikut langkah terpadu yang dapat dilakukan untuk menciptakan gerakan kewirausahaan sosial dalam diri pemuda pemudi Kota Bandung diantara yakni melalui (1). Memasukan kewirausahaan sebagai kurikulum resmi setiap level pendidikan mulai sekolah dasar hingga pendidikan tinggi (2). Menyesuaikan pola belajar mengajar dengan semangat atau spirit kewirausahaan yaitu mendorong guru sebagai fasilitator yang meramu pengalaman dan kreativitas pendidik, memperbolehkan perbedaan pendapat dalam proses belajar, mengapresiasi ide dan gagasan yang diberikan.

\section{SIMPULAN}

Praktik kewirausahaan sosial merupakan sebuah alternatif berbasis masyarakat yang berpotensi menyempurnakan proses pembangunan. Hal ini tentunya mendorong kita untuk dapat memecahkan permasalahan sosial bukan didasarkan kepada hal - hal yang bersifat patologis semata, melainkan melalui pengembangan potensi melalui kegiatan kegiatan yang menyenangkan. 


\section{DAFTAR PUSTAKA}

Budiharjo, Eko. 2014. Reformasi Perkotaan (dalam sub BAB artikel Mengembalikan Senyum Warga Kota). Penerbit Kompas.

Djakfar, Muhammad. 2012. Etika Bisnis Menangkap Spirit Ajaran Langit dan Pesan Moral Ajaran Bumi. Jakarta: Swadaya.
Kleniewski, Nancy. 1997. Cities, Change and Conflict: a Political Economy of Urban Life. Wardsworth Publishing Company.

Wibowo, Hery \& Soni A. Nulhaqim. 2015. Kewirausahaan Sosial: Merevolusi Pola Pikir dan Menginisiasi Mitra Pembangunan Kontemporer. Unpad Pers. Wibowo, Hery. 2015. Kewirausahaan Sosial Masyarakat Perkotaan. Unpad Pers. 